доцільним, оскільки відповідає вимогам до сучасних фахівців у царині освіти та передбачає орієнтацію на формування поряд із професійними знаннями, уміннями та навичками, оволодіння професійними IКТ, розвитком таких універсальних здібностей (IКТ-компетенцій), які затребувані сучасним ринком праці.

\title{
Література
}

1. Биков В. Ю. Сучасні завдання інформатизації освіти / В. Ю. Биков // Інформаційні технології i засоби навчання: електронне наукове фахове видання [Електронний ресурс]/ Ін-т інформ. технологій i засобів навчання АПН України, Ун-т менеджменту освіти АПН України; гол. ред.: В. Ю. Биков. - 2010. № 1(15). - Режим доступу:

http://www.ime.edu-ua.net/em15/emg.html. 2. Государственные образовательные стандарты высшего профессионального образования: перспективы развития : [монографія]/[кол. авт.; под ред. Я. И. Кузьминова, Д. В. Пузанкова, И. Б. Федорова, В. Д. Шадрикова]. - М. : Логос, 2004. - 328 с.3. Грубінко В. В. Формування інноваційного освітнього середовища у ВНЗ в контексті вимог Болонського процесу // Освіта як фактор забезпечення стабільності сучасного суспільства: матеріали міжнародної науково-теоретичної конференції (м. Тернопіль, 26 березня 2004 р.). - Тернопіль: Вид-во ТДПУ, 2004. С. 6-17. 4. Зеер Э. Компетентностный подход к модернизации профессионального образования : дайджест / Э. Зеер, Э. Сыманюк // Психология обучения. - 2006. № 2. - С. 28-31. - Полностью ст. опубл.: Высшее образование в России. -2005. № 4. - С. 23-30.5. Зимняя И. А. Социально-профессиональная компетентность как целостный результат профессионального образования: (идеализированная модель) / И. А. Зимняя // Проблемы качества образования. Компетентностный подход в профессиональном образовании и проектировании образовательных стандартов. М. : Исследовательский центр проблем качества подготовки специалистов, 2005. С. 10-20.6. Плахотнік О. Компетентнісний підхід у ВНЗ : Проблеми та перспективи /

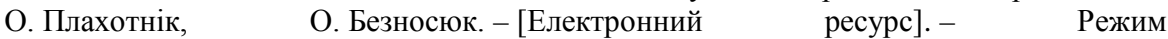
доступу :http://www.kspu.kr.ua/download/conf2013/section5/article_plahotnik.pdf.

7. Спірін О. М. Теоретичні та методичні засади професійної підготовки майбутніх учителів інформатики за кредитно-модульною системою: монографія[Електронний ресурс] / О. М. Спірін; за наук. ред. акад. М. І. Жалдака. - Житомир : Вид-во ЖДУ ім. I. Франка, 2007. - 300 с. - Режим доступу : http://lib.iitta.gov.ua/459.8. Татур Ю. Г. Компетентность в структуре модели качества подготовки специалиста / Ю. Г. Татур // Высшее образование сегодня. - 2004. - № 3. - С. 20-26.9. Шадриков В. Д. Новая модель специалиста: инновационная подготовка и компетентностный подход/ В. Д. Шадриков // Высшее образование сегодня. - 2004. - № 4. - С. 28-31.

УДК 78.071.2:786 (07)

Олена Ярошенко, Тетяна Пономаренко

\section{ІНТОНАЦЙНА ПРИРОДА МУЗИКИ В КОНТЕКСТІ ХОРЕОГРАФІЧНОГО МИСТЕЦТВА}

Ярошенко О. М., Пономаренко Т. В. Інтонаційна природа музики в контексті хореографічного мистецтва.

У статті розглядається поняття інтонації як знакової умовної форми в суміжних видах мистецтва - музиці і хореографії. Простежується інтонаційний взаємозв'язок між мовою, музикою, танцем, виокремлено чинники вияву інтонації в хореографії, складники хореографічної інтонації у порівнянні з музичною, наведено практичні прийоми усвідомлення поняття інтонації учнями. 
Ключові слова:інтонація, інтонаційний жест, звуковий жест, музика, хореографія.

Ярошенко Е. Н., Пономаренко Т. В. Интонационная природа музыки в контексте хореографического искусства.

В статье рассматривается понятие интонации как знаковой условной формы, присущей смежным видам искусства- музыке и хореографии. Прослеживается интонационная взаимосвязь между языком, музыкой, танцем, выделены факторы проявления интонации в хореографии и составляющие компоненты хореографической интонации в сравнении с музыкальной, приведены практические приемы усвоения понятия интонации школьниками.

Ключевые слова: интонация, интонационный жест, звуковой жест, музыка, хореография.

Yaroshenko E. M. Ponomarenko T. B. Intonational nature of music in the context of choreographic art.

The concept of intonation as an important conditional form, which is inherit to the contiguous kinds of art-music and choreography, is considered in the article. The relationship between speech intonation, music, dance is traced. Factors of manifestation of intonation in choreography and component parts of choreographic intonation in comparison with the musical one are highlighted. The practical receptions of mastering intonation concepts are provided.

Key words:intonation, intonational gesture, sound gesture, music, choreography.

Однією 3 актуальних $\mathrm{i}$ недостатньо розроблених проблем сучасного мистецтвознавства можна вважати проблему досліджень музичних понять у суміжних видах мистецтв, шляхи їх взаємозв'язку і взаємозбагачення. У більшості випадків хореографію розглядають як діяльність, яка уможливлює отримання візуальноемоційної насолоди від краси виконання рухів, як гармонійне поєднання музики і танцю. При цьому зазначений погляд на хореографію недостатньо розкриває значущість інтонаційного жесту у створенні пластичного образу.

Проблема підготовки студентів хореографічної спеціальності у вищих педагогічних закладах нині $є$ актуальною й неоднозначною. У царині музичної освіти майбутніх хореографів залишається багато неузгоджених питань i проблем, які потребують нагального розв'язання: поверхово-пропагандистський підхід до викладання музичних дисциплін, недостатність міждисциплінарних зв'язків, ствердження в хореографічній освіті професійно-просвітницького підходу до музичного мистецтва тощо [10, с. 235]. Ураховуючи історично-педагогічний досвід у системі підготовки вчителів музики, шлях подолання наявних проблем, на нашу думку, значною мірою залежить від рівня теоретичного усвідомлення музичних понять (у цьому випадку поняття інтонації), сформованості практичних виконавських навичок (м'язово-рухових відчуттів інтонації), що дозволяють установити і використовувати зв'язки музичних понять 3 дисциплін музично-теоретичного циклу (гра на фортепіано, теорія музики, основи диригентської та вокальної культури) 3 профільними предметами навчального плану підготовки майбутніх хореографів. Навичок, які, на думку фахівців, у подальшому становленні вчителя хореографії «дають змогу осягнути цілісний світ художньої творчості як процес спілкування митця зі світом духовних цінностей та як практичне їх ствердження в суспільному житті» [6, с. 56]. Дослідження поняття інтонації, що виявляється у двох видах мистецтва-хореографії і музиці не є на сучасному етапі досконалими, всупереч концепту інтонаційності, який 
давно увійшов до тезаурусу хореографічного мистецтва.

Питанням вивчення музичної інтонації займались ще древні греки. Можливість припущення щодо існування вчення про інтонування засвідчує акторська гра в давньогрецькому театрі, яка вимагала від виконавців не тільки декламування, але й співів [4, с.6]. Увагу поняттю інтонації приділяли відомі драматурги і режисери минулого сторіччя: В. Мейєрхольд, К. Станіславський, О. Таїров, М. Чехов. Так, М. Чехов у своєму вченні про «психологічний жест» підкреслював важливість для актора осмисленого інтонування слів і рухів, розглядав звукову сторону слова як рух, що перетворюється в звук - звуковий жест [7].

Важливий внесок до скарбниці вчення про інтонування внесли К. Глюк, А. Гретрі, О. Даргомижський, М. Мусоргський, Ж.-Ж. Руссо, О. Сєров. Категорія «інтонація» розглядається в дослідженнях, пов'язаних з проблемами стилю, жанру, музичної мови, тематизму, мелодики, гармонії, форми. Варто зазначити праці М. Арановського, Б. Асаф'єва, В. Бобровського, Л. Мазеля, В. Медушевського, Є. Назайкинського, О. Ручєвської, С. Скребкова, Ю. Тюліна, Б. Яворського та ін. Найбільш повне розроблення теорії інтонування належить Б. Асаф'єву.

Серед дослідників нового покоління на увагу заслуговують погляди музикознавця А. Ладигіної, яка стверджувала, що первинність танцю сприяла поширенню поняття інтонації та розповсюдженню його на інші види мистецтв, дослідження А. Адамкової щодо проблем пластичного інтонування, Ю. Абдокова про музичну поетику в хореографії, В. Ванслова щодо проблем інтонації в музиці і балеті. Ідею осягнення музики за умов вільного руху вивчала і практикувала С. Рудньова; дослідження Д. Кірнарської і О. Герасимової присвячені проблемам осягнення інтонаційних i аналітичних параметрів у музиці шляхом «тілесного мислення», «тілесного пізнання». Нині з'являються дослідження психологічної, терапевтичної спрямованості, такі, як: «Психологія тілесної свідомості» В. Нікітіна, «Усвідомлення через рух» М. Фельденкрайза, «Невербальна семіотика» Г. Крейдліна.

Значну кількість праць науковців присвячено проблемам опанування хореографічного мистецтва в системі вищої педагогічної освіти (О. Кравчук, О. Отич, О. Реброва, Ю. Ростовська, М. Чемберджі).

Mema cmammi- розкрити поняття інтонації як знакової умовної форми в суміжних видах мистецтва - музиці та хореографії.

Аналіз праць із теми дослідження дозволив 3'ясувати, що концепт інтонаційності як якості, що притаманна виключно мистецтву музичному, заперечується сутністю і естетичною спрямованістю інтонаційної теорії Б. Асаф’єва. Із концепції інтонації Б. Асаф'єва виходить, що інтонація як соціальне явище $\epsilon$ властивістю не тільки музичного мистецтва. Вона складає досить важливий компонент не тільки людської мови, але й мови пластичної [9, с. 8]. У передмові до книги Б. Асаф’єва «Музична форма як процес» О. Орлова визначає інтонування взагалі як вияв думки [1, с. 4]. Для нашого дослідження дане зауваження має особливий смисл, тому що розглядає поняття інтонації, яка $є$ невід'ємним складником будь-якого художнього відображення почуттів, емоцій, руху, що інформує про емоційно-психічний стан людини. Б. Яворський використовував учення про інтонацію для жанрових характеристик музики, що споріднює ii 3 мистецтвом пластичним, а інтонацію розглядав як знакову умовну форму, притаманну всім видам мистецтва. У цій єдності дослідник убачав ту нову якість, яка перетворює інтонацію з просто народного явища на чинник людської культури [9, с. 7]. Отже, інтонація - це найважливіша властивість не тільки музики, але й знаково-умовна якість, зумовлена соціальними функціями мистецтва та його загальнолюдським призначенням. 
Термін «інтонація» походить від латинського «intono» і позначає «проговорюю як розспів, заспівую». Термін виник спочатку в мовознавстві, де позначав «тон» мови, який включав всі зміни голосу - підвищення, пониження, - паузи і ступінь злитності звучання висловлювань, членування на фрази, групи слів, гучність їх змін [2, с. 35].

Термін «інтонація» має в музикознавстві два основних значення: у вузькому, суто прикладному, - це показник чистоти відтворення музичних звуків. У широкому - це та якість, яка кваліфікує музичний матеріал як художньо-змістовний. Музична інтонація це виразно-змістовна єдність, реалізована в невербальній звуковій, спрямовано-діючій формі, яка функціонує за допомогою досвіду музично-змістовних і позамузичних асоціативних уявлень. Саме мелодія, будучи головним носієм тематизму, $є$ інтонаційно максимально концентрованою і в інтонаційному складі музичної тканини виходити на перший план (висотний, мелодичний, ладогармонічний, тембровий, ритмічний). Глибоке усвідомлення інтонаційності сприяє розвитку мелодичного «звукового мислення».

Б. Асаф'єв стверджував, що музичне мистецтво постійно відчуває вплив «німої інтонації» пластики і руху людини». Музична інтонація, згідно 3 його поглядами, ніколи не втрачала зв'язків ні зі словом, ні з танцем, ні 3 мімікою людського тіла [1, с. 78]. Музична інтонація $є$ тілесною за своєю формою: вона осмислюється диханням, голосовими зв'язками, мімікою, жестами, тобто цілісним рухом тіла. При цьому інтонаційне осягнення музики грунтується на накопиченні «духовно-тілесного словника», під яким ми розуміємо сукупність згорнутих емоційно-тілесних відчуттів.

Не викликає сумнівів той факт, що певний музичний звук викликає в нас уявлення про відповідний рух. Ми «чуємо» жест, який $\epsilon$ кодом звукової форми. Зазначений жест присутній і поза звуками мовлення, але ми не сприймаємо його так само легко, як звук музичний - нам заважає змістовне насичення. Абстрагуючись від змісту слів, людина має змогу почути їх звучання, а разом 3 ним і жест, що криється за цим звучанням. Художня мова визначається не стільки змістом, як звуковим жестом [8].

Термін «інтонаційний жест» часто використовується в поезії, паралінгвістиці, терапевтичній логопедії. Терміном «інтонаційний жест» користувались відомі літературні критики для характеристики віршів різних поетів, критики і теоретики театру, музиканти, наприклад Я. Друскін у дослідженні «Про риторичні прийоми в музиці І. Баха».

Поняття інтонації в площині візуального мистецтва не ідентично інтонації, яку ми чуємо, але воно подано в тезаурусі хореографічного мистецтва достатньо тривалий час. Інтонація характеризує «виразний тонус», емоційне забарвлення мистецького образу як у музиці, так і в пластиці хореографічного жесту. Поняття інтонації було перенесено до галузі танцю, хореографії, балету досить закономірно в силу того, що зазначені види пластичного мистецтва грунтуються на виразності руху так само, як музика використовує виразні можливості мовної інтонації. Тобто, витоком, матеріалом таких видів мистецтв, як музика і хореографія є людина, іiі голос, жест, рух, пластика руху [3]. Явище інтонації в хореографії виявляється в таких чинниках: прагненні руху до набуття статусу музикального; якостях, які є особливо важливими в поданні нюансування пози та жесту; завершенні пластичних фраз; високому ступені стилізації жестів та їх відповідному емоційному забарвленні.

У своєму дослідженні ми зробили спробу виокремити складники інтонаційної виразності в хореографії у порівнянні з інтонаційними засобами музичної виразності. До них належать:

- рисунок танцю, здійснений у просторовому переміщенні, що можна порівняти із звуковою висотно-інтонаційною лінією мелодії, інтонаціями гармонічного комплексу;

- ритм танцю, представлений чергуванням у часі більш-менш значимих фігур, зумовлений інтонаційною структурою музичної побудови; 
- інтенсивність танцю - сила, наповнення, амплітуда руху, яка вимірюється інтонаційною інтенсивністю мелодичних інтервалів;

- темп танцю - цільність ліній, емоційно-експресивні відтінки, що зумовлюється зміною інтонаційних побудов;

- синтаксис танцю - побудова ліній, завершеність частин, вступ, завершення, моменти «очікування», «сольні» епізоди тощо, що тотожні синтаксису музичному (вступ, фраза, речення, речитатив).

Отже, тембр, гнучкість, регістр - поняття музичні - характеризують масу тіла, що рухається; темп і ритм передають швидкість та інтенсивність руху; звуковисотна лінія - спрямованість руху, траєкторію; метр, акценти, артикуляція (штрихи)характер руху (плавний, чіткий, розмірений, нервовий, рішучий, млявий, граційний. Характер звуковисотної лінії, наприклад, асоціюється у слухачів з певним рисунком, профілем. Мелодичний інтервал - не тільки з окремим жестом, кроком, стрибком, у першу чергу він має якісно-просторові координати і характеристику: за простором вузький, широкий, дуже широкий і емоційну (за музичним теоретиком Кірнбергом) рішучий, поривчастий, знесилений тощо. Співставлення регістрів і голосів асоціюється зі зміною простору (звуженням, розширенням), динамічне наростання i затухання - 3 просторовим переміщенням.

3 іншого боку, осягнення інтонації в музиці засобом м'язово-рухових відчуттів зацікавили і музичну педагогіку, про що свідчать дослідження в галузі музичної психології, тілесно-орієнтованої терапії, драматичної терапії тощо. Тематика досліджень відкриває майбутнім хореографам нові можливості щодо осмислення «онтогенетичних» механізмів емоційно-тілесного відчуття інтонаційної мови музики на рівні інтуїції, що досягається у процесі вивчення дисциплін музично-теоретичного циклу. Тілесний симптом допомагає усвідомити та інтуїтивно зрозуміти суб'єктивну музичну емоцію.

У практичній діяльності під час педагогічної практики під час пояснення дітям поняття «інтонація», студенти мають можливість розкрити зв'язок інтонації з живим, духовним началом у природі, в людині, яке має свій відповідний рух. Анімація неживого шляхом звукового видобування і підтвердження тілесним розумінням досить поширений художній прийом: Сосновий ліс перебирає струни / Рокоче тиша на глухих басах / Бринять берези. I блукають луни, / Людьми забуті з вечора в лісах. (Л. Костенко). Дихання, рух, душа - три ознаки живого, що символізують інтонаційну вражальність у мистецтвах. Інтонація - це «живий», одушевлений звук і рух у просторі [5, с. 273]. На простих і добре відомих дітям прикладах студенти можуть розкрити залежність яскравості хореографічного образу, який добре запам'ятовується, від стану виразності його інтонацій, порівнюючи його з образом музичного супроводу. Задля цього студентам необхідно дібрати твори з емоційно-виразними інтонаціями, які гарно передають людські почуття (жалоби, радощів, весняного пробудження, болю тощо). Особливо привертають увагу дітей твори з моторно-танцювальними інтонаціями, які передають динаміку руху або гри (В. Косенко «Полька», М. Мусоргський «Гопак», С. Прокоф’єв «Тарантела», Р. Шуман «Сміливий вершник» тощо).

Сприйняття музики під час руху є їі тілесним пізнанням і тілесним розумінням, чинники, які перебувають у проміжному, серединному положенні між розумним i підсвідомим сприйняттям і встановлюють зв'язок між почуттям і розумом в процесі сприйняття музики [8]. Задля підкреслення інтонації жесту корисно використовувати в молодших класах засоби музично-ритмічних рухів, такі, як пластичне інтонування й тактування скоромовок, текстів пісень, вільного диригування текстів, музики, віршів, імітації гри на музичних інструментах, пластичні етюди будь-якого створеного образу, інсценування пісні, нескладні танцювальні рухи. 
На сучасному етапі еволюції форм хореографічного мистецтва помітно збагачується інтонаційний рівень жестів і рухів, ведуться пошуки нових «інтонаційних резонансів» сучасного театру хореографії, здійснюється розроблення нової інтонаційної абетки жестів. Перспективи подальших розвідок дослідження полягають у виокремленні етапів формування в майбутніх хореографів практичних навичок емоційно-тілесного відчуття інтонаційної мови музики, розробленні методичних прийомів вивчення музично-теоретичних дисциплін задля опанування інтонаційним словником жестів.

\section{Література}

1. Асафьев Б. В. Музыкальная форма как процесс / Б.В. Асафьев: в 2-х книгах. Кн. 2. Интонация. - Л., 1963. - 212 с. 2. Асафьев Б. В. Речевая интонация / Б. В. Асафьев / М. - Л. : Музыка, 1965. - 136 с. З. Бабич Н. Ф. Интеграция музыкальных концептов в пластическом театре.-[Електронний ресурс].- Режим доступу: http://akademia.4net.ru. 4. Быкова Э. В. Эстетическая сущность музыкальной интонации : автореферат дис. на соискание ученой степени канд. филос. наук/ Э. В. Быкова. - М. : МГУ, 1969. - 18 с. 5. Побережна Г. І. Загальна теорія музики: [підручник] / Г. І. Побережна, Т.В. Щериця. - К. : Вища шк., 2004. - 303 с.: іл. 6. Психология музыкальной деятельности. Теория и практика / общ. ред Г. М. Цыпин / М. : Просвещение, 1984. - 176 с. 7. Чехов М. О технике актера. Психологический жест [Електронний ресурс]. - Режим доступу: http://drugie-berega.my1.ru. 8. Эмоционально-телесное постижение основ интонационного языка музыки // Развитие природной музыкальности на основе творческого музицирования [Електронний ресурс]. - Режим доступу: http://musike.blog.ru/ 9. Ярошенко О. М. Курс теорії музики 3 елементами гармонії в стислому викладенні [навч. посіб.]/ О. М. Ярошенко. - К., 1997. - 98 с. 10. Ярошенко О. М. Читання нот 3 листа на початковому етапі опанування музичною писемністю в системі підготовки вчителя хореографії/ Теорія і методика мистецької освіти: збірник наукових праць III Міжнародної науково-практичної конференції «Гуманістичні орієнтири мистецької освіти». - К. : НПУ ім. М. П. Драгоманова, 2009. - С. 235-241. 